BIOPROSPECÇÃO

\section{Novos métodos}

\section{para potencializar uso de microrganismos}

\section{marinhos}

Os oceanos entraram na pauta de discussão da reunião Rio+20 com a urgência de se determinar formas de preservá-lo. Ocupando cerca de 70\% do planeta, as águas salgadas abrigam uma biodiversidade ainda inexplorada, sobretudo quando se trata de microrganismos, seres invisíveis aos olhos, mas responsáveis por rica variedade de metabólitos e pela produção de oxigênio em níveis superiores a de plantas. Para as indústrias farmacêutica, biotecnológica e agrícola, um grupo potencial para a descoberta de novas drogas e substâncias. No entanto, pesquisadores alertam que os "microrganismos marinhos estão no topo da lista de organismos não cultivados com uso de métodos convencionais".

Em artigo de revisão, Hebe Dionisi, Mariana Lozada e Nelda Oliveira, pesquisadores do Centro Nacional Patagônico da Argentina, enfatizam que a maioria das técnicas de bioprospecçáo atuais ainda é deficiente para a completa exploração do potencial de microrganismos. Dentre as dificuldades de cultivo e crescimento em laboratório está a falta de condiçôes que mimetizem o habitat natural e que, portanto, impedem que esses organismos microscópicos se reproduzam e possam ser explorados.

DOMESTICAÇÃO O estudo, publicado na Revista Argentina de Microbiologia (Vol.44, 2012), lança luz sobre novas técnicas de bioprospecção disponíveis que podem modificar a desigual taxa entre as variedades (cepas) cultiváveis e não cultiváveis. "O gargalo desses métodos parece estar na adaptação das cepas cultivadas nas condições do laboratório (domesticação)", pontuam os autores.

"O exemplo mais extremo no qual o conhecimento ecológico foi chave no sucesso de cultivo está nos microrganismos simbiontes, cujas necessidades são altamente específicas em relação ao hospedeiro", afirmam Hebe e colegas. O meio de cultura utilizado deve, neste caso, reproduzir as condições proporcionadas pelo hospedeiro. Outra técnica apontada como promissora é a metagenômica que permite, por exemplo, a análise de DNA de uma comunidade de microrganismos, que geralmente são extremamente complexas. Sem a necessidade de cultivo, a extração do material genético pode ser feita a partir de amostras coletadas no meio ambiente e que podem incluir centenas e até milhares de diferentes taxas. O DNA é então sequenciado, analisado e, quando possível, o gene ou grupos de genes de interesse são recuperados, sintetizados e clonados para a produção dos compostos desejados.

"A bioprospecção dessas comunidades, que envolvem a busca por produtos e atividades de interesse, está atualmente experimentando uma revolução graças ao desenvolvimento de um caixa de ferramentas metodológicas em expansão que permitem a reprodução da biodiversidade em profundidade nunca antes possível", concluem os pesquisadores. A solução para diversos e complexos problemas que pressionam a sociedade e o meio ambiente pode estar no fundo do mar esperando por um resgate.

Germana Barata
PÓS-GRADUAÇão

Cursos sobre bioprospecção

A bioprospecção tem se mostrado estratégica nos estudos da biodiversidade brasileira, sobretudo na exploração de produtos naturais. Neste cenário, as universidades brasileiras começam a oferecer cursos de pós-gradução para atender a uma demanda reprimida de profissionais. Este é o caso do mestrado em bioprospeção molecular oferecido pela Universidade Regional do Cariri (Urca), ao sul do Ceará. Desde 2007, o curso já formou 38 alunos e deve, em 2013, pleitear a abertura do doutorado na área. 0 objetivo do curso é lidar com a química de produtos naturais, biologia molecular estrutural e o estudo de polímeros e aminoácidos, sobretudo da flora e fauna dos biomas da região. Outros dois cursos de mestrado em bioquímica e bioprospecção existem nas universidades Federal do Pampa (Unipampa) e de Pelotas (UFPel), desde 2011. Há ainda o curso de biologia geral e bioprospecção da Universidade Federal de Grande Dourados (UFGD) no Mato Grosso do Sul, desde 2011. E na região de maior biodiversidade do país, desde 2003, há o mestrado em biotecnologia e recursos naturais da Universidade Estadual do Amazonas (UEA). $O$ etnoconhecimento a a bioprospecção, no entanto, são uma das linhas de pesquisa disponíveis. 